\title{
Pemanfaatan limbah sampah sebagai media pembelajaran agama Islam pada anak usia dini di tengah pandemic Covid-19
}

\author{
Rohita ${ }^{(1)}$, Miranda Nur Alami, \& Rizqi Maulida \\ Universitas Al Azhar Indonesia, Indonesia \\ *rohita@uai.ac.id
}

\begin{abstract}
The existence of the co-19 pandemic is the cause of the implementation of large-scale social restrictions (PSBB), which resulted in almost all Indonesian people can only carry out their activities at home. As a result of the high activity being carried out at home, the by-products in the form of garbage also increased a lot. Both organic and inorganic waste, which often cannot be utilized. On the other hand, the educational process that usually occurs in schools now has to move to the house, with the mother acting as a teacher. Of the many stimulation needs that must be obtained by early childhood, religious values become the main thing that needs to be instilled as a foundation for them to be able to live their lives later. The purpose of this activity is to improve the ability of parents to use waste as a medium of Islamic learning in children. The activity was carried out in the South Tangerang area, with 15 participants having pre-school age children. The activity was carried out using the method of presenting material using a zoom cloud meeting, giving video tutorials, presenting the results of the work, and giving assignments. The results of the activity show that there are many media that participants can produce based on waste, especially cardboard and plastic, to be used in Islamic religious learning in early childhood.
\end{abstract}

\begin{abstract}
Abstrak Adanya pandemik covid-19 menjadi penyebab diberlakukannya pembatasan social berskala besar (PSBB), yang mengakibatkan hampir seluruh masyarakat Indonesia hanya dapat melakukan aktivitasnya di rumah. Sebagai akibat tingginya aktivitas yang dilakukan di rumah, produk sampingan berupa sampah juga bertambah banyak. Baik sampah organik maupun anorganik, yang seringkali tidak dapat dimanfaatkan. Di sisi lain, proses pendidikan yang biasanya terjadi di sekolah kini pun harus berpindah ke rumah, dengan ibu yang berperan sebagai guru. Dari banyaknya kebutuhan stimulasi yang harus didapat anak usia dini, nilai agama menjadi hal utama yang perlu ditanamkan sebagai pondasi bagi mereka untuk dapat menjalani kehidupannya kelak. Tujuan kegiatan ini adalah untuk meningkatkan kemampuan orangtua dalam memanfaatkan limbah sampah sebagai media pembelajaran agama Islam pada anak. Kegiatan dilaksanakan di wilayah Tangerang Selatan, dengan jumlah peserta sebanyak 15 orang yang memiliki anak usia prasekolah. Kegiatan dilaksanakan dengan metode pemaparan materi menggunakan zoom cloud meeting, pemberian video tutorial, pemaparan hasil karya, serta pemberian tugas. Hasil kegiatan menunjukkan banyaknya media yang dapat dihasilkan peserta berbahan dasar limbah sampah, khususnya kardus dan plastik, untuk digunakan dalam pembelajaran agama Islam pada anak usai dini.
\end{abstract}

Keywords: non-organic waste; learning media; Islamic values

\section{ठ OPEN ACCESS}

Citation: Rohita, M. N. Alami, \& R. Maulida. (2021). Pemanfaatan limbah sampah sebagai media pembelajaran agama Islam pada anak usia dini di tengah pandemic Covid-19. Riau Journal of Empowerment, 4(2), 105-118. https://doi.org/10.31258/raje.4.2.105-118

Received: 2021-03-12 Revised: 2021-09-05 Accepted: 2021-09-15

Language: Bahasa Indonesia (id)

ISSN 2623-1549 (online), 2654-4520 (print)

(C2021 Rohita, Miranda Nur Alami, \& Rizqi Maulida. Author(s) retain the copyright of article published in this journal, with first publication rights granted to Riau Journal of Empowerment. The article is licenced under Creative Commons Attribution 4.0 International License. This license permits unrestricted use, distribution, and reproduction in any medium, provided the original author and source are credited. 


\section{PENDAHULUAN}

Berbagai lini kehidupan berubah drastic sejak wabah covid-19 merebak di hampir seluruh Negara di dunia, tidak terkecuali di Indonesia. Akibat yang ditimbulkan dirasakan oleh semua kalangan pada berbagai bidang, termasuk ekonomi dan pendidikan. Pada bidang ekonomi diantaranya adalah pemutusan hubungan kerja (PHK) dan dalam bidang pendidikan, proses pembelajaran tatap muka di sekolah berganti menjadi pembelajaran jarak jauh (PJJ) dengan sistem on-line. Orangtua menjadi pelaksana tugas guru di rumah dalam pendampingan anakanaknyadengan menggunakan sistem online. Sistem tersebut berlaku pula pada pendidikan untuk anak usia dini.

Berbagai tantangan tentu dihadapi orangtua dalam melaksanakan tugasnya sebagai "guru" ditengah keterbatasan pengetahuan mengenai proses pembelajaran dan hal-hal lain yang terkaitdenganhaltersebut. Banyak yang harus dipahami orangtua untuk dapat melaksanakan pendampingan kepada anak-anaknya agar kebutuhan anak dalam proses tumbuh dan kembangnya tercapai maksimal sesuai dengan usia, karakteristik dan kemampuan anak. Diantaranya adalah pemahaman mengenai materi dan media pembelajaran untuk anak usiadini.

Anak usiadini merupakan anak yang berada pada rentang usia 0-6 tahun yang membutuhkan berbagai stimulasi untuk mengembangkan berbagai aspek perkembangannya termasuk perkembangan nilai agama dan moral (Peraturan Menteri Pendidikan dan Kebudayaan Republik Indonesia No. 137 Tahun 2014/ Permendikbud RI). Dalam proses penanamannilai agama dan moral dibutuhkan media untuk membantu anak memahami materi yang disampaikan, mengingat kemampuan berpikir abstrak anak masih rendah.

Namun, tidak banyak media yang tersedia di rumah untuk dapat digunakan dalam proses pembelajaran dan penanaman nilai agama dan moral tersebut. Untuk pengadaannya sendiri dibutuhkan pengetahuan mengenai bahan dan cara membuat media. Di sisi lain, pengadaan media tidak bisa dihadirkan dengan cara membeli karena beban ekonomi akibat adanya PHK yang cukup memberatkan orangtua.

Berdasarkan permasalahan tersebut maka diperlukan solusi yang dapat membantu orangtua meningkatkan pemahamannya mengenai pembelajaran agama bagi anak usiadini serta meningkatkan kemampuan membuat media untuk pembelajaran agama tersebut. Solusi yang dilakukan adalah melalui kegiatan pengabdian kepada masyarakat dengan judul "pemanfaatan limbah sampah sebagai media pembelajaran agama Islam bagi anak usiadini di masa pandemik Covid-19”.

\section{Limbah sampah}

Sampah adalah sisa kegiatan sehari-hari manusia dan/atau proses alam yang berbentuk padat. Berdasarkan sifat fisik dan kimianya, sampah digolongkan menjadi: 1). sampah yang mudah membusuk, seperti sisa sayuran, sisa daging, daun dan lain-lain; 2). sampah yang tidak mudah membusuk, seperti plastik, kertas, karet, logam, sisa bahan bangunan dan lain-lain; 3). sampah yang berupa debu/abu; dan, 4. sampah yang berbahaya bagi kesehatan, seperti sampah berasal dari industri dan rumah sakit yang mengandung zat-zat kimia dan agen penyakit yang berbahaya (Anonim, 2008). Berdasarkan jenis sampah tersebut, sampah organic merupakan jenis sampah yang paling banyak dihasilkan yaitu sebanyak 60\%; sampah plastik 14\%; sampah kertas 9\%; metal 43\%; kaca, kayu dan bahan lainnya 12,7\% (BalitbangKemendagri, 2018). Data tersebut juga menunjukkan bahwa sampah non-organic tidak sebanyak sampah organik, 
namun keberadaannya lebih sulit ditangani terutama kaleng dan plastik yang sulit terurai secara biologis oleh alam (Ridwan et al., 2016), dan jika jumlahnya menumpuk di tanah akan mencemari lingkungan (Unilever, 2019).

Proses penguraian sampah-sampah tersebut juga tidak mudah, membutuhkan waktu berpuluh tahun bahkan ratusan tahun. Azanella (2018) mencatat bahwa kulit pisang membutuhkan waktu 2-5 minggu; pokok buah apel 2 bulan; kertas koran 6 minggu; kotak susu 3 bulan; batang rokok 1-5 tahun; tas belanja plastik 10-20 tahun; botol minuman bersoda yang terbuat dari kaleng alumunium 200 tahun; botol minuman plastic membutuhkan waktu 450 tahun; dan botol kaca membutuhkan waktu hingga 1 juta tahun untuk bisa hancur.

Dari sekian banyak jenis sampah yang ada, rumah tangga merupakan penghasil sampah paling banyakdi Indonesia (Rasio Ridho Sani dalam Prawira, 2014). Hal tersebut dikuatkan dengan pernyataan Andono, selaku Kepala Dinas Lingkungan Hidup Provinsi DKI Jakarta, yang menjelaskan bahwadari total 7.600 ton sampah yang dihasilkan per hari, sekitar $61 \%$ merupakan sampah rumah tangga (Iskandar, 2020). Untuk mengurangi jumlah timbulan sampah, cara yang paling mudah dilakukan adalah dengan menjualnya, terutama limbah sampah anorganik. Nugroho (2013) menuliskan, beberapa sampah anorganik yang dapat dijual adalah plastic wadah pembungkus makanan, botol dan gelas bekas.

Namun, tentunya ada cara lain selain langsung menjual limbah tersebut, yaitu dengan merubahnya menjadi barang baru yang dapatdigunakan sebagai kelengkapan rumah tangga, seperti membuat berbagai bentuk kerajinan serta asesoris, ataupun dijual untuk menambah penghasilan. Akan tetapi diperlukan pengetahuan yang lebih banyak terkait pengolahan limbah sampah anorganik tersebut. Doriza dan Putri (2014), menuliskan bahwa adanya pengetahuan dan pemahaman yang dimiliki ibu rumah tangga berdampak pada dihasilkannya berbagai produk diantaranya limbah botol plastik menjadi produk aksesoris; kreasi bunga artificial daribahanbotol dan sampahplastik (Diansari \& Adhivinna, 2019); serta membuat tempat gelas minuman berbahan dasar gelas minuman plastik, membuat tas dari bungkus kopi instan, serta membuat bunga dari plastik kresek (Fatoni et al., 2017). Semua hasil karya tersebut akan memberikan nilai jual yang lebih tinggi dibandingkan dengan menjual limbah sampah secara langsung tanpa merubahnya. Namun belum ditemukan pemanfaatan limbah sampah sebagai media pembelajaran bagi anak usiadini untuk menanamkan agama Islam terutama yang dibuat oleh orangtua, ibu-ibu rumah tangga.

\section{Media pembelajaran bagi anak usia dini}

Media pembelajaran adalah media yang dapatdigunakan untuk membantu anak didik dalam memahami informasi yang disampaikan, baik oleh guru di sekolah maupun orangtua di rumah. Di dalam Permendikbud RI Nomor 146 Tahun 2014 tentang Kurikulum 2013 Pendidikan Anak Usia Dini, penggunaan media pembelajaran menjadi salah satu prinsip pembelajaran bagi anak yang harus dipenuhi, dan pemanfaatan alam sebagai sumber belajar menjadi hal penting lainnya. Penggunaan media pembelajaran memberikan berbagai macam manfaat. Suprihatiningrum (2013) menuliskan manfaatnya, antara lain: proses pembelajaran menjadi lebih jelas, meningkatnya ketertarikan dan interaktivitas siswa, mengkonkretkan materi yang abstrak, membantu mengatasi keterbatasan panca indera manusia, dan meningkatkan daya retensi siswa terhadap materi pembelajaran. Senada dengan Suprihartiningrum, Karo-karo dan Rohani (2018) menuliskan dua keuntungan penggunaan media dalam pembelajaran yaitu becomes more clear and interesting, and become more interactive. 
Besarnya kebutuhan akan media pembelajaran terkadang tidak disertai dengan sumber dana yang mencukupi sehinggadiperlukan cara untuk dapat memperbaharui fasilitas pembelajaran berupa media yaitu dengan memanfaatkan bahan-bahan ekonomis yang ada, khususnyadari bahan-bahan sekitar (Khoiri, 2018). Adanya limbah sampah, baik organik maupun non organik, dapat menjadi solusi akan kebutuhan tersebut dengan memanfaatkannya sebagai bahan dasar pembuatan media. Namun, tidak semua limbah sampah dapat digunakan, seperti misalnya botol kaca. Hal ini terkait dengan kelompok usia anak dalam kategori usia dini yang belum dapat menggunakan media pembelajaran sesuai sifat bahan pembuat media tersebut dengan benar.

Dari jenisnya, media juga terbagi menjadi beberapa macam, yaitu visual, audio, dan audio visual. Media audio visual seperti video juga seringkali digunakan dalam pembelajaran. Pengaruh positif penggunaan video terhadap kemampuan peserta didik ditemukan salah satunya dari hasil penelitian Nurdin et al., (2019) yang menyatakan bahwa video pembelajaran berbasis Geogebra efektif dan berpengaruh positif terhadap peningkatan kemampuan pemahaman konsep Matematis siswa. Di masa pandemik covid-19 seperti saat ini, dimana pembelajaran dilakukan secara daring (dalam jaringan), penggunaan video pembelajaran tentu menjadi alternatif utama untuk dapat memahamkan peserta didik mengenai materi yang disampaikan.

\section{Pembelajaran agama Islam}

Salah satu materi pembelajaran yang harus diberikan kepada anak usia dini, khususnya yang beragama Islam, adalah materi tentang nilai-nilai agama Islam. Di dalam agama Islam, Al Quran dan Hadis merupakan sumber dari materi pembelajaran. Nilai-nilai yang terkandung di dalamnya mencakup akidah, ibadah dan akhlak. Nilai-nilai tersebut harus dipahami dan diamalkan dalam kehidupan sehari-hari, sehingga terbentuk perilaku Islami sebagaimana yang dicontohkan teladan umat Islam yaitu Nabi Muhammad SAW.

Pentingnya, orang tua memberikan pendidikan agama kepada anak, dituliskan Djaelani (2013) dalam hasil penelitiannya bahwa pendidikan agama yang diberikan orang tua kepada anaknya memiliki peran: 1). sebagai fondasi dalam keluargauntuk membentuk perilaku dan moral anak-anak dan mengetahui batasan baik dan buruk, 2). berfungsi untuk membentuk manusia yang percaya dan ketaqwaan kepada Allah SWT, serta 3). sebagai fondasi utama dan berperan dalam pendidikan moral bagi pembangunan masyarakat Indonesia seluruhnya. Muhammad (2012) menuliskan bahwa tugas yang paling utama orang tua adalah mendidik dan memberi ilmu pendidikan agama, akhlak dan ilmu-ilmu lain yang berguna baik bagi diri pribadinya maupun yang bemanfaat bagi masyarakat banyak. Besarnya tanggungjawab orang tua kepada anak-anaknya, membuat orang tua harus sungguh-sungguh berusaha untuk memberikan yang terbaik kepada mereka, tidak boleh lengah apalagi meninggalkan kewajibannya terutama dalam memberikan pendidikan agama.

\section{METODE PENERAPAN}

Kegiatan pengabdian kepada masyarakat dilakukan dengan beberapa metode, yaitu: 1). Pemaparan materi mengenai nilai agama Islam, sampah, dan media pembelajaran, serta pemberian video tutorial mengenai contoh pembuatan media pembelajaran sesuai dengan nilai agama Islam yang akan ditanamkan; 2). Demonstrasi pembuatan media menggunakan limbah 
sampah berbasis video tutorial; 3). Penugasan kepada peserta untuk membuat 1 media berbasis limbah sampah; dan, 4). Pemaparan hasil karya peserta dan evaluasi hasil karya. Metode kegiatan tersebut dilakukan dalam 3 sesi dimana 2 sesi pertama menggunakan aplikasi zoom cloud meeting, dan sesi ke-3 peserta mengumpulkan tugas membuat hasil karya dengan mengirimkan video proses pembuatan dan bentuk jadi melalui aplikasi whatsapp. Penggunaan aplikasi zoom cloud meeting dan whatsapp dikarenakan adanya pemberlakuan PSBB di wilayah Tangerang Selatan, yang tidak memungkinkan bagi tim pelaksana untuk melakukan kegiatan dalam bentuk tatap muka secara langsung di lokasi tersebut.

Bahan utama yang digunakan dalam kegiatan pengabdian kepada masyarakat ini adalah limbah sampah, seperti kardus, bungkus snack, gelas plastik bekas, dan lainnya. Bahan-bahan tersebut merupakan barang yang akan diolah menjadi media untuk menanamkan nilai-nilai Islam yang mencakup nilai akidah, ibadah, dan akhlak. Selain limbah sampah yang merupakan bahan utama, digunakan juga berbagai buku sebagai referensi materi mengenai nilai-nilai Islam, media pembelajaran, dan pengolahan sampah.

\section{HASIL DAN KETERCAPAIAN SASARAN}

Sebelum melaksanakan kegiatan pengabdian kepada masyarakat, orangtua didampingi untuk dapat menginstal aplikasi zoom cloud meeting yang akan digunakan sebagai media kegiatan. Merupakan tantangan tersendiri ketika melakukan pendampingan tersebut dikarenakan sebagian besar orangtua belum mengenal zoom apalagi menggunakan aplikasi tersebut. Pendampingan tidak hanya saat menginstal tetapi juga mengajari cara untuk dapat bergabung atau join meeting dan memfungsikan peralatan seperti speaker dan video agar dapat digunakan dengan tepat saat kegiatan. Satu jam sebelum kegiatan dimulai, pesertadiberikan kuesioner untuk mengetahui pemahaman peserta mengenai materi yang akan disampaikan dengan menggunakan aplikasi google form.

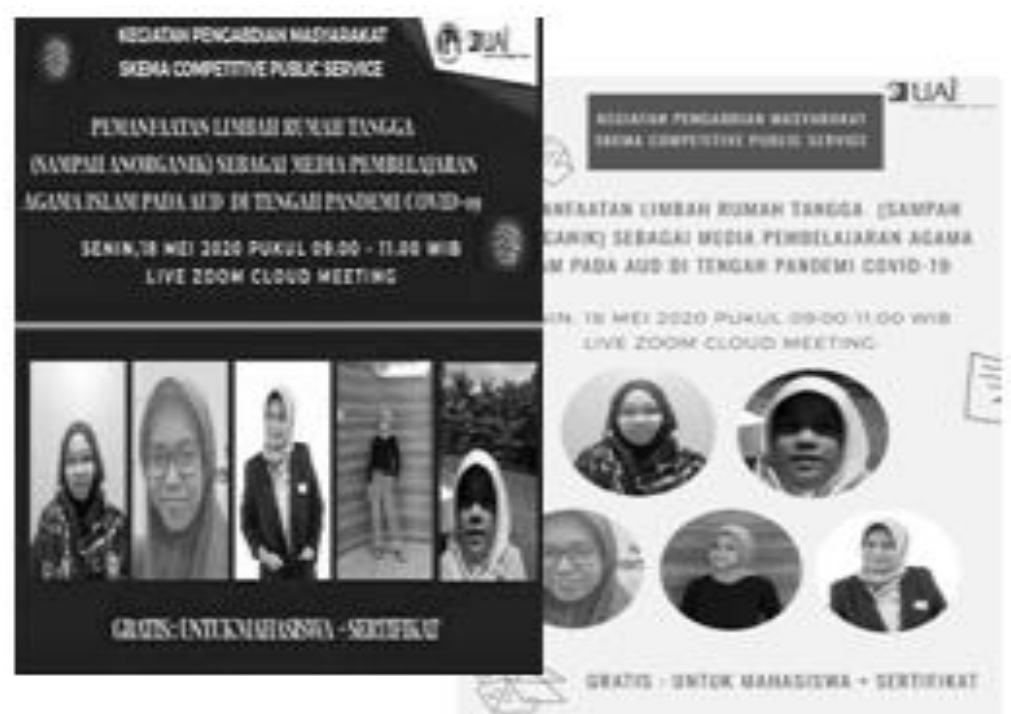

Gambar 1. Poster kegiatan pengabdian masyarakat 


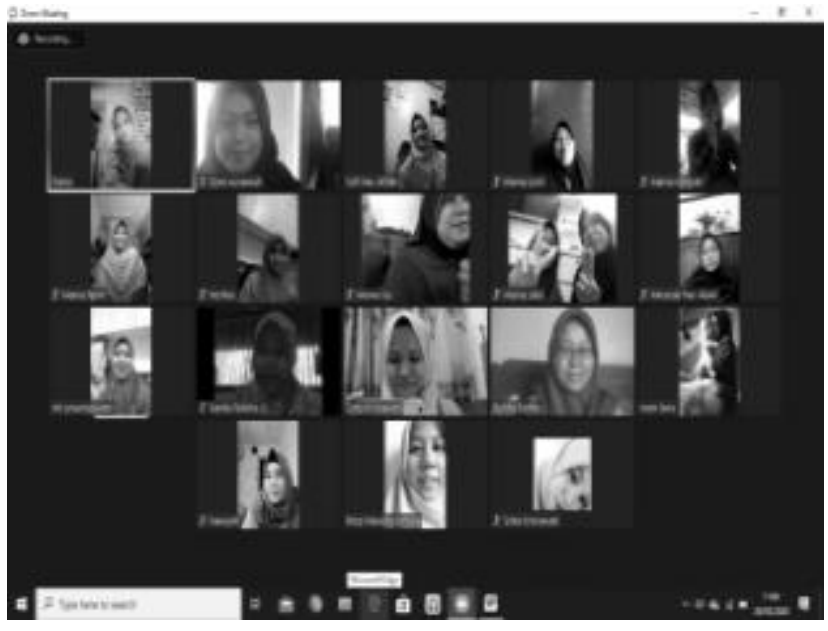

Gambar 2. Peserta kegiatan

Pertemuan pertama kegiatan pengabdian masyarakat dilaksanakan pada Senin, 18 Mei 2020 dan dimulai pada pukul 09.00 WIB. Kegiatan diawali pembacaan rangkaian acara oleh MC dilanjutkan dengan sambutan dan pembukaan kegiatan yang disampaikan Dr. Fidesrinur, M.Pd. sekaligus sebagai ketua program studi pendidikan guru pendidikan anak usia dini, Universitas Al Azhar Indonesia. Selanjutnya penyampaian materi oleh Dewi Asnawiah mengenai sampah dan pengolahannya, materi media pembelajaran pada anak usia dini oleh Miranda Nur Alami, serta materi mengenai nilai agama Islam yang mencakup nilai akidah (rukun iman), ibadah (rukun islam dan bentukpelaksanaannya), dan akhlak (perbuatanperbuatan sesuai sunnah Rasulullah SAW) disampaikan oleh Rizqi Maulida Amalia, M.Si. Kemudian untuk lebih memahamkan peserta mengenai materi yang telah disampaikan, khususnya mengenai pembuatan media berbahan dasar limbah sampah, diberikan video tutorial. Kegiatan dilanjutkan dengan Tanya jawab serta pemaparan mengenai tugas yang harus dilakukan peserta untuk pertemuan berikutnya serta pemberian kuesioner untuk mengetahui ada atau tidaknya perubahan pemahaman terutama mengenai limbah sampah dan pemanfaatannyasebagai media pembelajaran agama Islam untuk anak usia dini.

Pertemuan kedua tetap dilaksanakan menggunakan zoom cloud meeting, pada Rabu, 20 Mei 2020. Kegiatan dilaksanakan mulai pukul 09.00-11.00 WIB. Setelah pembukaan, kegiatan dilanjutkan dengan meminta peserta memaparkan hasil karya atau media yang telah jadi dengan menjelaskan alat dan bahan yang digunakan serta nilai agama yang akan ditanamkan kepada anak.

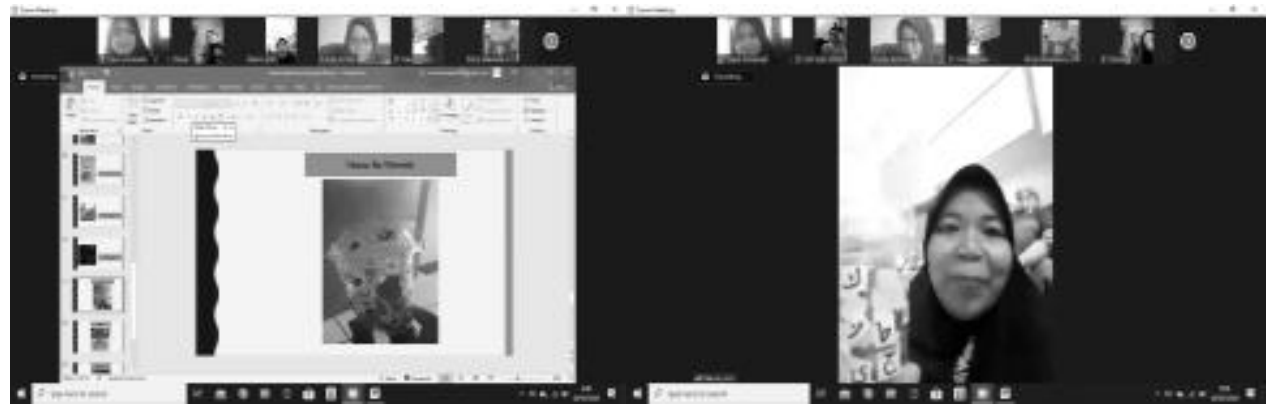

Gambar 3. Presentasi media yang telahdibuat oleh peserta

Kegiatan dilanjutkan dengan melakukan evaluasi baik terhadap bentuk media, pembuatan media agar berfungsi lebih maksimal, serta penggunaannya dalam usaha menanamkan nilai 
Agama Islam kepada anak. Evaluasi juga dilakukan terhadap nilai Agama Islam agar peserta benar-benar paham terhadap apa yang akan ditanamkan sesuai dengan ajaran Islam. Kegiatan yang dilakukan pada pertemuan ketiga adalah memberikan tugas kepada peserta untuk membuat media pembelajaran dengan menggunakan limbah sampah. Untuk memotivasi peserta dalam membuat media, pelaksana membuat challenge dan memberikan reward bagi peserta yang dapat memenuhi tugas yang diberikan. Informasi disampaikan melalui whatsapp group untuk memudahkan komunikasi sekaligus memantau kemajuan dari pelaksanaan tugas yang diberikan kepada peserta. Tugas dikirimkan pesertadalam bentuk video proses pembuatan serta foto media pembelajaran yang telah jadi. Waktu yang diberikan kepada peserta untuk menyelesaikan tugas tersebut adalah delapan (8) hari sejak Kamis, 11 Juni hingga Kamis, 18 Juni 2020.

Setelah kegiatan selama tiga (3) pertemuan selesai, dilakukan olah data terhadap kuesioner yang diberikan sebelum dan setelah kegiatan pengabdian masyarakat.

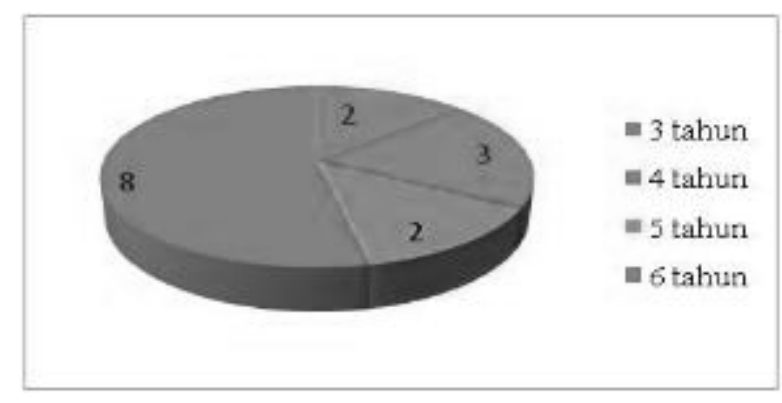

Gambar 4. Usia anak peserta

Berdasarkan gambar 4, diketahui bahwa peserta memiliki anak usia dini yang sebagian besar berusia 6 tahun dan 4 tahun, dan terdapat anak berusia 3 tahun sebanyak 2 orang. Anak dengan rentang usia 3-6 tahun merupakan anak dalam kelompok usia dini, yaitu usia yang memerlukan banyak stimulasi untuk dapat mengembangkan berbagai potensi yang dimilikinya, termasuk potensi beragama, khususnya agama Islam. Terkait dengan nilai agama Islam yang harus ditanamkan kepada anak, Fatah (2008) menyatakan bahwa terdapat 3 nilai utama yaitu, akidah, ibadah, dan akhlak.

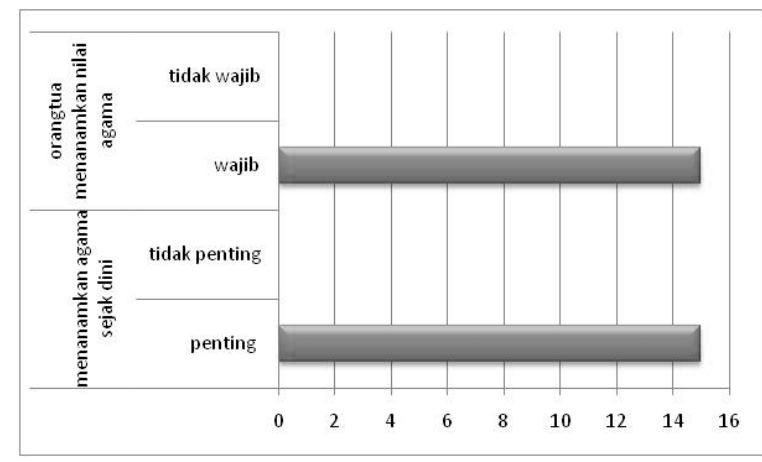

Gambar 5. Pentingnya menanamkan agama sejakdini dan pelaksana penanaman agama

Dari gambar 5, terlihat bahwa seluruh orang tua menjawab penting untuk menanamkan agama kepada anak sejak dini. Hal ini dilakukan dengan alasan agar anak memiliki akhlak yang baik, mengenal agama lebih baik, mengetahui mana yang baik dan yang tidak, menjadi pondasi bagi hidupnya, sertamemiliki kehidupan yang baik di masa depannya. Hal ini senadadengan yang disampaikan oleh Djaelani (2013). Selain penting, orangtua juga 
menyadari bahwa menanamkan nilai agama merupakan kewajiban orangtua, sebagaimana disampaikan Muhammad (2012) bahwa tugas yang paling utama orang tua adalah mendidik dan memberi ilmu pendidikan agama. Tugas utama merupakan hal yang harus dilakukan sehingga menjadi sebuah kewajiban yang tidakdapat diabaikan apalagi ditinggalkan. Berdasarkan hasil kuesioner, nilai agama yang ditanamkan orangtua meliputi salat, mengaji, rukun iman, rukun Islam, serta berbuat baik. Salat, mengaji, dan rukun Islam merupakan bagian dari nilai ibadah, rukun iman bagian dari nilai akidah, dan berbuat baik bagian dari nilai akhlak. Artinya peserta telah memahami bahwa nilai agama Islam terdiri dari nilai akidah, nilai ibadah, dan nilai akhlak (Fatah, 2008) yang harus ditanamkan kepada anak sejak dini.

Penanaman nilai agama bukanlah sesuatu yang mudah, mengingat anak dalam rentang usia 3-6 tahun secara kognitif berada pada tahap praoperasional, artinyaanak dapat memahami sesuatu apabiladisertai dengan benda konkrit yang dapat dilihat atau dimanipulasi. Untuk mengatasinya diperlukan media yang sesuai agar anak dapat menerima stimulasi yang diberikan dan pengetahuan yang disampaikan dengan lebih mudah. Adanya media pembelajaran membuat proses pembelajaran yang diberikan lebih jelas sehingga perhatian anak lebih panjang, anak lebih tertarik dan juga interaktif. Hal tersebut merupakan beberapa manfaat yang bisa didapatkan dari penggunaan media pembelajaran sebagaimana disampaikan Karo-Karo \& Rohani (2018) serta Suprihatiningrum (2013).

Di sisi lain penanaman nilai agama dalam bentuk pembelajaran umumnya lebih banyak diterima anak usia 3- tahun dari guru ketika anak berada di sekolah. Stimulasi diberikan secara terstruktur dan sistematis dalam bentuk pembiasaan-pembiasaan serta menggunakan berbagai media untuk mengenal akidah, ibadah, dan akhlak. Namun adanya pandemik Covid-19 serta pemberlakuan pembatasan sosial berskala besar (PSBB), kegiatan tersebut berpindah kepada orangtua yang dilakukan di rumah.

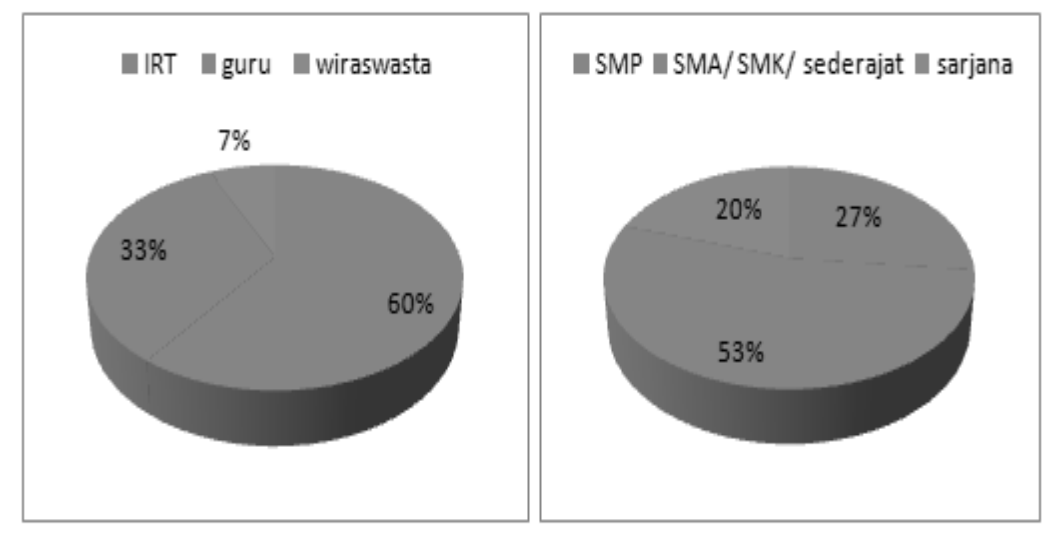

Gambar 6. Pekerjaan peserta dan tingkat Pendidikan

Berdasarkan gambar 6 diketahui bahwa sebagian besar pekerjaan peserta adalah ibu rumah tangga dengan latar belakang pendidikan terbanyak adalah SMA/SMK/sederajat. Menjadi sebuah tantangan bagi orangtua terutama dengan pekerjaan sebagai ibu rumah tangga untuk dapat membuat media pembelajaran, khususnya pembelajaran agama Islam. Ditambah dengan pekerjaan sebagai ibu rumah tangga yang seolah-olah pekerjaan di rumah tidak akan pernah selesai. Pengetahuan mengenai media pun mungkin tidak terlalu banyakdimiliki jikadibandingkan dengan peserta yang berprofesi sebagai guru. Adanya pengetahuan terhadap suatu hal akan memberikan pengaruh terhadap sikap atau tindakan yang akan dilakukan terkait dengan hal tersebut, baik untuk pencegahan maupun untuk merubah kehidupan menjadi lebih baik. 
Meskipun belum ditemukan hasil penelitian mengenai hubungan atau pengaruh pengetahuan orangtua mengenai media pembelajaran dengan kemampuan membuat media pembelajaran, tetapi beberapa penelitian lain telah membuktikan adanya hubungan atau pengaruh pengetahuan dengan sebuah kemampuan atau perilaku tertentu. Diantaranya adalah penelitian mengenai pengetahuan ibu tentang menggosok gigi dengan perilaku ibu dalam menggosok gigi di TK Pamekar Budi Kulonprogo (Asda \& Rahayu, 2017), pengetahuan orang tua tentang stimulasi dini terhadap perkembangan anak (Kosegeran et al., 2013), serta pengetahuan orangtua tentang stimulasi verbal dengan perkembangan bahasa anak prasekolah di TK PGRI 116 Bangetayu Wetan (Handayani et al., 2013).

Membuat media tentu membutuhkan bahan dasar, yang dapat diperoleh dari berbagai sumber, termasuk limbah sampah. Untuk mendapatkannya diperlukan pengetahuan mengenai makna limbah sampah dan sifat dari limbah sampah tersebut. Sampah anorganik merupakan salah satu jenis limbah sampah yang perlu mendapat perhatian lebih karena sifatnya yang tidak mudah hancur. Berdasarkan kuesioner yang diberikan sebelum pemaparan materi dalam kegiatan pengabdian masyarakat, delapan (8) dari 15 orang peserta memberikan jawaban bahwa sampah anorganik adalah sampah yang sulit terurai (3 orang), susah hancur (1 orang), sampah yang bisa didaur ulang (3 orang), sampah yang dihasilkan dari bahan non hayati. Hanya satu (1) orang yang menyatakan bahwa sampah anorganik merupakan sampah yang bisa hancur, seperti sampah sayuran. Adapun lima (5) orang lainnyatidak menjelaskan mengenai makna sampah anorganik melainkan menyebutkan contoh sampah anorganik yaitu kardus dan botolplastik.

Selanjutnya, untukdapat memanfaatkan sampah anorganik, seluruh peserta setuju dan menyatakan penting untuk melakukan daur ulang, dan menyatakan bahwa sampah anorganik bisa diubah menjadi media pembelajaran agama Islam.

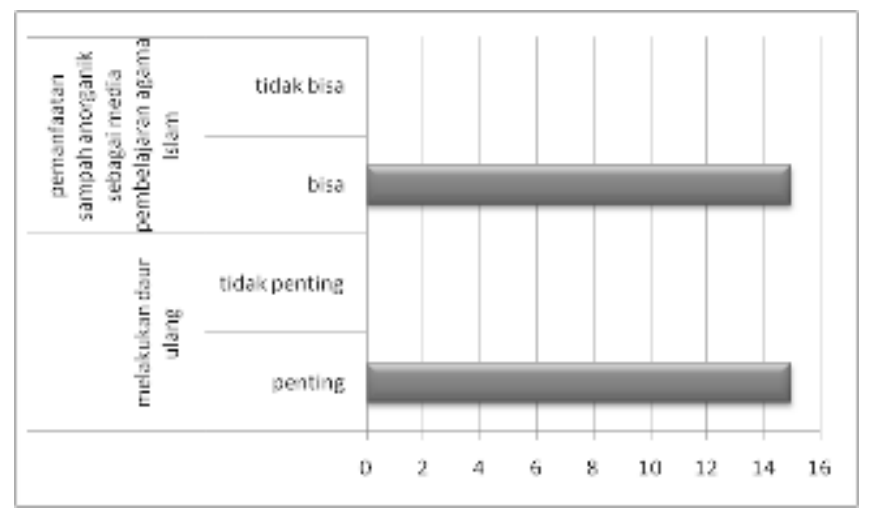

Gambar 7. Pentingnya melakukan daur ulang dan pemanfaatannya

Berdasarkan hasil kuesioner mengenai pemanfaatan limbah sampah sebagai media pembelajaran agama Islam, diperolah jawaban sebagai berikut. Dari 15 peserta, lima (5) orang hanya menjawab "ya" tanpa memberikan contoh; enam (6) orang menyebutkan contoh media yang dapat dibuat berupa pot bunga, boneka, prakarya, tempat pensil, dan hiasan tangan; dan empat (4) orang menyebutkan untuk membuat jam dari tutup botol untuk mengajarkan waktu solat, celengan dari botol atau kaleng bekas untuk mengajarkan menabung, dan kardus bekas untuk mengajarkan huruf hijaiyah. Dari data tersebut terlihat hanya 4 orang peserta yang menyebutkan media pembelajaran agama yang dapat dibuat dari limbah sampah. Untuk dapat mewujudkan media pembelajaran agama Islam, delapan (8) peserta menjawab dengan cara 
memilah dan mendaur ulangnya, sementara tujuh (7) peserta lainnya menjawabnya dengan berbagai macam hal seperti sampah tidak terurai, pot bunga, dan lain sebagainya.

Adanya peningkatan pemahaman diketahui berdasarkan jawaban dalam kuesionar setelah pemaparan materi dan pemberian video tutorial. Terkaitdengan pengetahuan mengenai sampah anorganik sebanyak 14 orang peserta atau $93.33 \%$ telah memberikan jawaban yang lebih sempurna dimana yang dimaksud dengan sampah anorganikadalah sampah yang tidak dapat diuraikan oleh alam, terbuat dari bahan non hayati/ bahan tambang, dan dapat didaur ulang, seperti kardus, botol plastik, dan kaleng bekas. Hanya 1 peserta atau $6.67 \%$ yang masih keliru dalam memahami sampah anorganik dengan menjawab sampah yang mudah hancur seperti sampah sayuran.

Berdasarkan hasil kuesionar tersebut, diketahui pula, bahwa 9 pesertamenyebutkan media pembelajaran agama Islam dapatdibuatdari kardus, yaitu untuk menulis huruf-huruf hijaiyah; dibuat puzzle baik puzzle huruf hijaiyah, puzzle rukun iman, dan puzzle rukun islam, puzzle perbuatan baik dan buruk; pohon hijaiyah; serta pohon rukun iman dan rukun Islam. Untuk sampah anorganik, seperti gelas plastic ataupun botol plastic kecil bekas minuman, dapat digunakan sebagai wadah tempat mengelompokkan wayang perbuatan baik dan buruk yang terbuatdari kertas dan stik bekas. Gelas plastik bekas minuman seperti bubble ice juga dapat dibuat sebagai wadah kocokan berisi gulungan kertas yang bertuliskan huruf hijaiyah. Selain itu sampah anorganik juga dapat dibuat celengan boneka Islami. Ide tersebut kemudian diwujudkan dalam media bentuk jadi dan dipresentasikan pada pertemuan kedua. Bahkan peserta mampu membuat lebih dari ide yang dituliskan semula. Kemudian agar media tersebut dapat terwujud, sebanyak 14 peserta atau $93.33 \%$ menjawab dengan cara dipilah kemudian di daur ulang. Hanya 1 peserta yang memberi jawaban berbeda. Olah data juga dilakukan dengan mencermati hasil karya yang telah dibuat peserta dalam menyelesaikan tugas challenge.

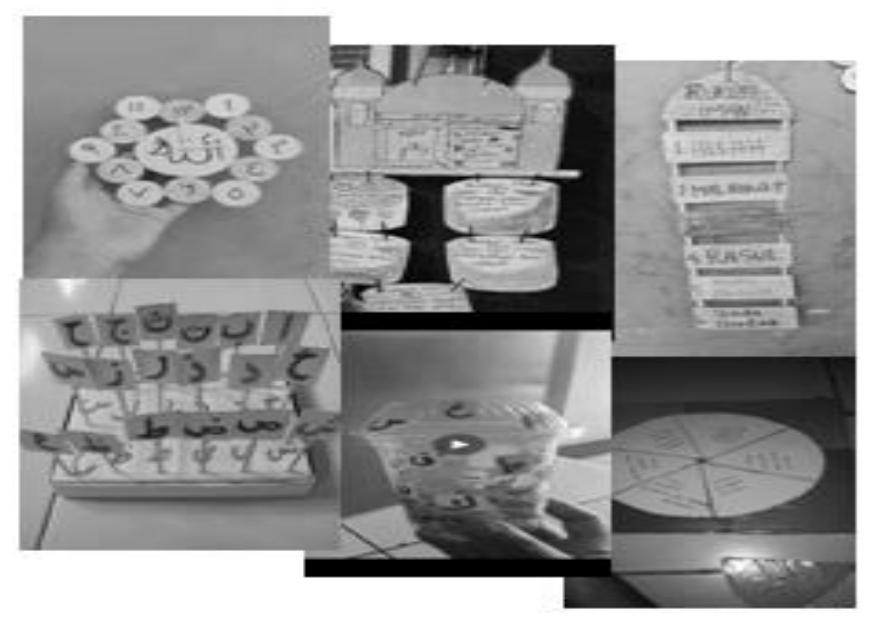

Gambar 8. Media pembelajaran hasil karya peserta

Apabila disajikan dalam bentuk tabel, maka adanya peningkatan pemahaman mengenai cara mengolah limbah sampah serta kemampuan orangtua dalam membuat media pembelajaran agama Islam dapat terlihat pada tabel berikut. 
Tabel 1. Media pembelajaran berbasis sampah anorganik

\begin{tabular}{|c|c|c|c|c|}
\hline No & $\begin{array}{l}\text { Ide media sebelum } \\
\text { kegiatan }\end{array}$ & $\begin{array}{l}\text { Ide media sesudah } \\
\text { kegiatan }\end{array}$ & $\begin{array}{l}\text { Media yang } \\
\text { dipresentasikan }\end{array}$ & Media hasil challenge \\
\hline 1. & Membuat pot bunga & $\begin{array}{l}\text { membuat huruf } \\
\text { hijaiyah }\end{array}$ & kipas rakaat salat & $\begin{array}{l}\text { stik kebaikan dan keburukan; } \\
\text { kincir rakaat solat }\end{array}$ \\
\hline 2. & membuat celengan & membuat celengan & botol dan kartu hijaiyah & $\begin{array}{l}\text { pohon waktusolat; papan rukun } \\
\text { iman; stik rukun islam }\end{array}$ \\
\hline 3. & membuat prakarya & $\begin{array}{l}\text { membuat jam dari } \\
\text { tutup botol plastic } \\
\text { untuk mengajarkan } \\
\text { waktu solat }\end{array}$ & papan hijaiyah & $\begin{array}{l}\text { stik hiijaiyah; papan rukun } \\
\text { islam; angka arab }\end{array}$ \\
\hline 4. & $\begin{array}{l}\text { membuat jam dari tutup } \\
\text { botol plastic untuk } \\
\text { mengajarkan waktu } \\
\text { solat }\end{array}$ & $\begin{array}{l}\text { merubah plastic } \\
\text { menjadi barang } \\
\text { berguna }\end{array}$ & papan rukun Iman & $\begin{array}{l}\text { pohon rukun islam; huruf } \\
\text { hijaiyah; waktu solat }\end{array}$ \\
\hline 5. & Iya, botol minuman & $\begin{array}{l}\text { membuat huruf } \\
\text { hijaiyah }\end{array}$ & bunga hijaiyah & \\
\hline 6. & membuat boneka & $\begin{array}{l}\text { Ya, membuat media } \\
\text { pembelajaran contoh } \\
\text { celengan boneka } \\
\text { islamiah, pohon } \\
\text { hijaiyah }\end{array}$ & papan nama Allah & $\begin{array}{l}\text { celengan haji; puzzle hijaiyah; } \\
\text { stik rukun islam }\end{array}$ \\
\hline 7. & $\begin{array}{l}\text { membuat kerajinan } \\
\text { tangan, hiasan rumah }\end{array}$ & puzzle hurufhijaiyah & stick hijaiyah & pohonhijaiyah \\
\hline 8. & iya & $\begin{array}{l}\text { Bisa } \\
\text { membuat huruf }\end{array}$ & celengan & \\
\hline 9. & iya & $\begin{array}{l}\text { hijaiyah dari botol dan } \\
\text { kardus bekas }\end{array}$ & papan hijaiyah & \\
\hline 10. & memberi makan ternak & $\begin{array}{l}\text { membuat pupuk } \\
\text { tanaman }\end{array}$ & papan rukun islam & \\
\hline 11. & $\begin{array}{l}\text { membuat celengan dari } \\
\text { botol atau kaleng bekas }\end{array}$ & $\begin{array}{l}\text { membuat puzzle huruf } \\
\text { hijaiyah }\end{array}$ & $\begin{array}{l}\text { stik solat wajib dan } \\
\text { sunah }\end{array}$ & $\begin{array}{l}\text { puzzle rukun islam; stik perilaku } \\
\text { baik buruk }\end{array}$ \\
\hline 12. & plastik, Koran & kaleng plastik & gelas hijaiyah & kantung kebaikan dan keburukan \\
\hline 13. & $\begin{array}{l}\text { membuat bunga dari } \\
\text { botol }\end{array}$ & $\begin{array}{l}\text { membuat puzzle huruf } \\
\text { hijaiyah }\end{array}$ & gelas hijaiyah & \\
\hline 14. & Ya. botol & $\begin{array}{l}\text { membuat pohon rukun } \\
\text { iman dan rukun islam }\end{array}$ & bedug & \\
\hline 15. & Iya, tempat pensil & $\begin{array}{l}\text { membuat huruf } \\
\text { hijaiyah }\end{array}$ & bunga hijaiyah & $\begin{array}{l}\text { bunga huruf hijaiyah; papan } \\
\text { lafadz Allah; papanwaktusolat }\end{array}$ \\
\hline$\sum$ & 2 & 11 & 15 & 21 \\
\hline
\end{tabular}

Dari tabel 1 terlihat perbedaan media yang diusulkan dan dibuat oleh peserta. Berdasarkan jumlahnya terdapat peningkatan yang signifikan. Meskipun saat pemberian tugas terdapat 6 peserta yang tidak dapat mengikuti challenge dengan alasan diantaranya tidak memiliki waktu yang cukup untuk menyelesaikan tugas. Video tutorial sebagai salah satujenis media audio visual yang digunakan sebagai metode kegiatan memberikan pengaruh positif terhadap peningkatan kemampuan orangtua peserta kegiatan. Hal iniditemukan pula pada penelitian yang dilakukan Elvida dan Ardisal (2018) yang menyatakanbahwa video tutorial is effective in improving the skills of making lip balm for deaf people in Gerkatin. Serta, penelitian Fadhilla dan Armaini (2020), yaitu making a board garland using a video tutorial shows an excellent improvement for students and teachers.

Meskipun media yang dibuat peserta lebih banyak menggunakan limbah sampah organic berupa kardus dan kertas, dan hanya beberapa peserta yang menggunakan sampahan organik berupa botol dan gelas plastic bekas minuman tetapi kemampuan dan kemauan merupakan modal utama untuk dapat melakukan hal yang lebih banyak dan lebih baik, terutama untuk mendukung pembelajaran bagi anak usiadini serta berpartisipasi dalam menjaga lingkungan alam. Sekecil apapun peran orangtua sebagai bagian dari masyarakat untuk dapat memanfaatkan limbah sampah akan berdampak besar bagi lingkungan. Meskipun jumlah 
sampah kertas dan kardus (9\%) tidak sebanyak jumlah sampah botol atau gelas plastik (14\%), serta masa hancurnya kardus ( 2 bulan) dan kertas (6 minggu) juga tidak selama masa hancur sampah botol atau gelas plastik (450 tahun) (Azanella, 2018), namun Dayana (2019) menuliskan bahwa jika didaur ulang maka sampah kertas akan mengurangi banyak volume sampah di tempat pembuangan.

Pentingnya keberadaan media pembelajaran membutuhkan ketersediaan alat dan bahan yang cukup untuk pembuatannya serta cepat dalam perolehannya. Hal tersebut dapat diatasi dengan menyediakan tempat penampungan limbah sampah terutama sampah yang dapat didaur ulang. Adanya tempat penampungan sampah juga dapat membantu masyarakat khususnya peserta kegiatan dalam mensiasati keterbatasan dana yang seringkali menjadi hambatan dalam usaha mengadakan media pembelajaran. Terlebih berlakunya PSBB yang mengakibatkan banyak terjadinya pemutusan hubungan kerja (PHK), sehingga himpitan ekonomi terasa semakin berat. Manfaat tersebut seperti yang disampaikan Asteria dan Heruman (2016) bahwa Bank Sampah Pucuk Resik (BSPR) di Kampung Karanggresik memberikan manfaat diantaranya kemandirian warga secara ekonomi.

Meningkatnya kemampuan orangtua peserta kegiatan dalam membuat media pembelajaran merupakan hal yang positif terutama di tengah masa pandemik covid-19 dan PSBB. Dengan kemampuan dan kemauan yang dimiliki tersebut, disertai pengetahuan mengenai limbah sampah dan nilai agama Islam, maka peran orangtua sebagai pendidik bagi anak-anaknya, terutama selama masa pandemic dapat dilakukan secara maksimal.

\section{KESIMPULAN}

Kesimpulan dari hasil kegiatan ini adalah $100 \%$ peserta kegiatan mampu memanfaatkan limbah sampah dan merubahnya menjadi media pembelajaran agama Islam untuk anak usia dini, yang dapat dilihat dari berbagai produk media yang dihasilkan. Meningkatnya kemampuan tersebut terjadi setelah mendapatkan informasi melalui pemaparan materi serta menyaksikan video tutorial proses pembuatan media. Peserta juga diberikan tugas untuk membuat mediadengan pendampingan tim pelaksana. Orangtua juga telah memahami bahwa menanamkan nilai agama Islam sejak dini merupakan hal yang penting dan wajib dilakukan orangtua, sehingga hal tersebut juga menjadi motivasi peserta dalam membuat media pembelajaran selain untuk menjaga lingkungan alam dari limbah sampah. Saran yang dapat diberikan adalah agar pihak RT atau RW setempat dapat menyediakan tempat penampungan limbah sampah sehingga masyarakat dapat memanfaatkan dan mengolahnya menjadi barang yang bernilai lebih, terutama untuk membuat media pembelajaran agama Islam, khususnya, bagi anak usia dini.

\section{UCAPAN TERIMA KASIH}

Terimakasih disampaikan kepada Lembaga Penelitian dan Pengabdian kepada Masyarakat Universitas Al Azhar Indonesia (LP2M UAI) atas pendanaan dalam skema competitive public service grant yang diberikan, serta seluruh peserta kegiatan pengabdian kepada masyarakat di wilayah Tangerang Selatan. 


\section{Daftar Pustaka}

1. Anonim. (2008). Undang-undang Nomor 18 Tahun 2008 tentang Pengelolaan Sampah. Jakarta.

2. Fadhilla, N., Armaini. (2020). Meningkatkan keterampilan membuat karangan bunga papan melalui media video tutorial pada anak tuna rungu. Indonesian Journal of Instructional Technology. 1(1), 46-54.http://journal.kurasinstitute.com/index.php/ijit

3. Asda, P., \& Rahayu, N.H. (2017). Hubungan tingkat pengetahuan ibu dengan perilaku ibu dalam mendidik anak menggosok gigi. Jurnal kesehatan masyarakat, 10(2), 812-821. http://jurnal.stikeswirahusada.ac.id/jkm/article/view/89

4. Asteria, D., \& Heruman, H. (2016). Bank sampah sebagai alternative strategi pengelolaan sampah berbasis masyarakat di Tasikmalaya. Jurnal Manusia dan Lingkungan, 23(1), 136-141. Doi: $10.22146 / \mathrm{Jml} .18783$.

5. Azanella, L.A. (2018). Butuh waktu lama bagi bumi untuk mengurai sampah dan plastik. https://sains.kompas.com/read/2018/11/21/174018423/butuh-waktu-lama-bagi-bumi-untukmengurai-sampah-dan-plastik?page $=2$

6. BalitbangKemendagri. (2018). Riset: 24 persen sampah di Indonesia masih tak terkelola. Jakarta. http://litbang.kemendagri.go.id/website/riset-24-persen-sampah-di-indonesia-masih-takterkelola/\#: :text=Riset\%20terbaru\%20Sustainable\%20Waste\%20Indonesia, dan\%20lingkungan \%20karena\%20tidak\%20ditangani. Diakses 21 Juni 2020, 11.36 am.

7. Dayana, A.S. (2019). Mengenal jenis sampah yang perlu waktu lama untuk hancur. https://tirto.id/mengenal-jenis-sampah-yang-perlu-waktu-lama-untuk-hancur-ejFk. Diakses 21 Juni 2020. $11.37 \mathrm{am}$.

8. Diansari, RE., \&Adhivinna, V.V., (2019). Pendampingan dan pelatihan pemanfaatan limbah masyarakat menjadi produk bernilai guna tinggi kepada ibu rumah tangga yang tergabung dalam rumah kreasi castle dengan binaan dinas lingkungan hidup, Jurnal Berdaya Mandiri, 1(1),1-8. Doi: $10.31316 / \mathrm{Jbm} . V 1 \mathrm{i1} .222$.

9. Djaelani, S. (2013). Peran Pendidikan Agama Islam dalam Keluarga dan Masyarakat.

10. Doriza, S., \&Putri, V.U.G. (2014). Pemanfaatan limbah botol plastic melalui pelatihan wirausaha produk aksesoris bagi ibu rumah tangga. Sarwahita: Jurnal PengabdianKepada Masyarakat,11(2), 99-108.

DOI: https://doi.org/10.21009/sarwahita.112http://journal.unj.ac.id/unj/index.php/sarwahita/issue /view/447.

11. Elvida, R., \& Ardisal. (2018). Efektivitas media video tutorial terhadap keterampilan membuat lip balm bagi tuna rungu. Jurnal Penelitian Dan Pendidikan Khusus, 6(2), 172177.http://ejournal.unp.ac.id/index.php/jupekhu/article/view/101696

12. Fatah, Y. (2008). Dimensi - dimensi Pendidikan Islam. Malang: Malang Press.

13. Fatoni, N., Imanuddin, L. R., \&Darmawan, A.R. (2017). Pendayagunaan sampah menjadi produk kerajinan. DIMAS, 17(1), 83-96. DOI: http://dx.doi.org/10.21580/dms.2017.171.1505.

14. Handayani, A. Samiasih, A., \&Mariyam. (2013). Hubungan tingkat pengetahuan orang tua tentang stimulasi verbal dengan perkembangan bahasa pada anak prasekolah Di TK PGRI 116 Bangetayu. Fikkes: Jurnal Keperawatan ,6(2), 7682.Http://103.97.100.145/Index.Php/Fikkes/Article/View/1876/1918

15. Iskandar, R.A. (2020). Pemprov DKI targetkan pengurangan sampah hingga 30 persen. http://www.beritajakarta.id/read/77240/pemprov-dki-targetkan-pengurangan-sampah-hingga-30persen\#.Xu57AsQzbMw

16. Kementerian Pendidikan dan Kebudayaan RI. (2014). Peraturan Menteri Pendidikan dan KebudayaanRepublik Indonesia No. 137 Tahun 2014 tentang Standar Nasional Pendidikan Anak Usia Dini. Jakarta.

17. Kementerian Pendidikan dan Kebudayaan RI. (2014). Peraturan Menteri Pendidikan Dan Kebudayaan Republik Indonesia Nomor 146 Tahun 2014 Tentang Kurikulum 2013 Pendidikan Anak Usia Dini. Jakarta. 
18. Kosegeran, H.B., Ismanto, A. Y. \& Babakal, A. (2013). Hubungan tingkat pengetahuan orangtua tentang stimulasi dini dengan perkembangan anak usia 4-5 tahun di DesaRanoketang Atas. Jurnal Keperawatan, 1(1), 1-8. https://ejournal.unsrat.ac.id/index.php/jkp/article/view/2187.

19. Muhammad, A.R. (2012). Pendidikan agama: sebuah kewajiban rumah tangga pada peringkat awal. Jurnal: Ilmiah Didaktika. XII(2), 272-288.DOI: http://dx.doi.org/10.22373/jid.v12i2.453

20. Khoiri, M., \& Harsono. (2018). Pengolahan sampah anorganik menjadi media pembelajaran. Loyalitas: Jurnal Pengabdian kepada Masyarakat, 1(2), 87-96.

21. Nugroho, P. (2013). Panduan membuat kompos cair. Jakarta: Pustaka Baru Press.

22. Nurdin, E., Ma’aruf, A., Amir, Z., Risnawati, R., Noviarni, N., \&Azmi, M.P. (2019).

Pemanfaatan video pembelajaran berbasis Geogebra untuk meningkatkan kemampuan pemahaman konsep matematis siswa SMK. Jurnal Riset Pendidikan Matematika, 6(1), 87-98. DOI: https://doi.org/10.21831/jrpm.v6i1.18421

23. Prawira, A.E. (2014). Sampah di Indonesia paling banyak berasal dari rumah tangga. https://www.liputan6.com/health/read/831503/sampah-di-indonesia-paling-banyak-berasal-darirumah-tangga

24. Ridwan, I., Nurfaida, \& Katriani, M. (2016). Pemanfaatan sampah anorganik menjadi produk berdayaguna. Jurnal Dinamika Pengabdian, 1(2), 123-133. http://journal.unhas.ac.id/index.php/jdp/article/view/2196

25. Karo-karo, I.R., \&Rohani. (2018). Manfaat media dalam pembelajaran. Axiom: Jurnal Pendidikan dan Matematika, 7(1), 91-96. DOI: http://dx.doi.org/10.3082/axiom.v7i1.1778.

26. Suprihatiningrum, J. (2013). Strategi pembelajaran teori dan aplikasi. Yogyakarta: AR-Ruzz Media.

27. Unilever. (2019). Panduan Pemilahan Sampah Di Rumah. Https://www.Unilever.Co.Id/Id/Images/Panduan-Pemilahan-Sampah-2019_Tcm1310543969 1 Id.Pd 